\title{
Understanding the benefit of metformin use in cancer treatment
}

\author{
Ryan JO Dowling ${ }^{1}$, Pamela J Goodwin ${ }^{2}$ and Vuk Stambolic ${ }^{*}$
}

Abstract
Biguanides have been developed for the treatment of
hyperglycemia and type 2 diabetes. Recently,
metformin, the most widely prescribed biguanide, has
emerged as a potential anticancer agent.
Epidemiological, preclinical and clinical evidence
supports the use of metformin as a cancer
therapeutic. The ability of metformin to lower
circulating insulin may be particularly important for
the treatment of cancers known to be associated with
hyperinsulinemia, such as those of the breast and
colon. Moreover, metformin may exhibit direct
inhibitory effects on cancer cells by inhibiting
mammalian target of rapamycin (mTOR) signaling and
protein synthesis. The evidence supporting a role for
metformin in cancer therapy and its potential
molecular mechanisms of action are discussed.

\section{A brief history of biguanides}

The biguanides metformin, phenformin and buformin are derived from the herb Galega officinalis (French lilac, also known as Goat's Rue or Italian Fitch) and were originally developed for the treatment of hyperglycemia and type 2 diabetes. Use of tea infused with French lilac for relief of frequent urination (polyuria) and halitosis (a sweet odor on breath), both now well known symptoms of diabetes, dates back to ancient Egypt and medieval Europe [1-3]. Work in the $1920 \mathrm{~s}$ identified biguanides as the active compounds from the French lilac and led to their development as therapeutics in the $1950 \mathrm{~s}[1,3,4]$. While phenformin and buformin were withdrawn from the market in the $1970 \mathrm{~s}$ due to toxicity related to lactic acidosis, metformin $\left(N^{\prime}, N^{\prime}\right.$ dimethylbiguanide) remains one of the most commonly prescribed drugs, with nearly 120 million prescriptions

\footnotetext{
* Correspondence: vuks@uhnres.utoronto.ca

'Ontario Cancer Institute, University Health Network, Toronto, Ontario, Canada

Full list of author information is available at the end of the article
}

filled yearly worldwide [5]. Metformin was approved for the treatment of hyperglycemia in Britain in 1958, Canada in 1972, and the US in 1995. In addition to its use in diabetics, metformin is also effective in the treatment of polycystic ovary syndrome and is being explored as an antiviral and anticancer agent [5-7]. Indeed, the use of biguanides in oncology was originally initiated in a series of studies targeting altered metabolism in non-diabetic cancer patients [8-10]. More recently, metformin has been associated with decreased cancer incidence and mortality in diabetic patients and the insulin-lowering effects of metformin may be integral to its anticancer properties [5,11-13]. Here, we discuss the use of metformin in oncology and its potential mechanisms of action in the inhibition of cancer.

\section{Discussion}

\section{Mechanism of metformin action}

At the cellular level, metformin activates AMP-activated protein kinase (AMPK), an energy sensor involved in regulating cellular metabolism that is activated by increases in the intracellular levels of AMP $[14,15]$. Metformin indirectly activates AMPK by disrupting complex I of the mitochondrial respiratory chain, which leads to decreased ATP synthesis and a rise in the cellular AMP: ATP ratio [16]. Increased association of AMPK with AMP under such conditions leads to stimulation of AMPK activity by three mechanisms. AMP allosterically activates AMPK and facilitates phosphorylation of its catalytic subunit on residue Thr172 by the upstream kinase liver kinase B1 (LKB1, also known as STK11), the protein product of the tumor suppressor gene mutated in the Peutz-Jeghers cancer predisposition syndrome [17]. Binding of AMP to AMPK also prevents dephosphorylation of AMPK Thr172 by protein phosphatases. Activated AMPK phosphorylates a number of downstream targets leading to stimulation of catabolic processes that generate ATP, such as fatty acid $\beta$-oxidation and glycolysis, and suppression of many of the processes dependent on ample cellular ATP supply, including 
gluconeogenesis, protein and fatty acid synthesis and cholesterol biosynthesis $[18,19]$.

The mechanism of metformin action in the treatment of diabetes involves the inhibition of hepatic gluconeogenesis and the stimulation of glucose uptake in muscle $[20,21]$. These effects are achieved by AMPK-mediated transcriptional regulation of genes involved in gluconeogenesis in the liver and those encoding glucose transporters in the muscle, such as peroxisome proliferator-activated receptor- $\gamma$ coactivator $1 \alpha(\mathrm{PGC}-1 \alpha)$ and glucose transporter type 4 (GLUT4), respectively $[5,22,23]$. Consequently, metformin enhances insulin sensitivity and lowers fasting blood glucose and insulin in diabetics.

\section{Metformin and cancer}

The potential for application of metformin in oncology was first recognized in retrospective epidemiological studies of diabetic patients with cancer. Numerous observational studies reported decreased cancer incidence and cancer-related mortality in diabetics receiving standard doses of metformin (1500 to $2250 \mathrm{mg} /$ day in adults) [11,24-28]. For example, Evans and colleagues [11] reported a reduced risk of subsequent cancer diagnosis in diabetics receiving metformin (vs those patients not receiving the drug), with the protective effect increasing with greater metformin exposure. Additional studies examining all forms of cancer have reported reduced cancer risk in diabetics on metformin (vs no metformin treatment $[24,27]$ ) and lower cancer-related mortality in patients receiving metformin compared to those receiving other standard diabetic therapies [28]. Furthermore, a recent epidemiological study of 2,529 women with breast cancer reported higher pathologic complete response rates (pCRs; considered a surrogate for overall survival in this setting) to neoadjuvant systemic therapy in diabetic patients receiving metformin (pCR 24\%) compared to diabetic patients not receiving metformin (pCR 8\%) and nondiabetic patients not receiving metformin (pCR 16\%)[29]. However, despite the increase in $\mathrm{pCR}$, metformin did not significantly improve the estimated 3-year relapse-free survival rate in this study. Moreover, in a similar study of diabetic prostate cancer patients, metformin use was not associated with benefit [30]. Thus, further clinical research is needed to fully appreciate the impact of metformin on cancer recurrence and survival.

While the majority of evidence supporting a role for metformin in the treatment of cancer has been derived from retrospective studies involving diabetics, some prospective clinical trials have been completed in nondiabetic patients. In a recent study, low doses of metfor$\mathrm{min}(250 \mathrm{mg} /$ day $)$ reduced the number of rectal aberrant crypt foci (a surrogate marker for colorectal cancer) and decreased the proliferative activity of colonic epithelium in non-diabetic patients [31]. Furthermore, interim analyses of ongoing studies involving neoadjuvant metformin treatment of newly diagnosed breast cancer patients have demonstrated that metformin is safe and well tolerated, and exhibits favorable effects on insulin metabolism and tumor cell proliferation and apoptosis [32,33].

Metformin also displays significant growth inhibitory effects in several cancer cell and mouse tumor models. In cell culture, metformin inhibits the proliferation of a range of cancer cells including breast, prostate, colon, endometrial, ovarian, and glioma [34-40]. The effects of metformin on cancer cell proliferation were associated with AMPK activation, reduced mammalian target of rapamycin (mTOR) signaling and protein synthesis, as well as a variety of other responses including decreased epidermal growth factor receptor (EGFR), Src, and mitogen-activated protein kinase (MAPK) activation, decreased expression of cyclins, and increased expression of $\mathrm{p} 27$. While not universally observed in all cells, metformin has been found to induce apoptosis in certain cell lines derived from endometrial cancers, glioma, and triple negative breast tumors [38,39,41].

Recent studies have demonstrated that metformin may also target cancer-initiating cells. For example, metformin inhibited the growth of a subpopulation of breast cancer cells shown to have such property in culture and reduced their ability to form tumors in mice [42] and when combined with trastuzumab, metformin reduced the cancerinitiating cell population in Her2-amplified breast cancer cells [43]. Interestingly, metformin may also be involved in regulating breast cancer-initiating cell ontogeny by transcriptionally repressing the process of epithelial to mesenchymal transition (EMT) [44]. Metformin also reduced the growth of a variety of tumor xenografts in mice including those established from breast and prostate cancer cells $[36,41]$, and suppressed the development of breast, colon and other tumors in transgenic mice [45,46]. In addition, metformin inhibited the development of chemically induced lung tumors and preneoplastic colonic lesions in mice $[47,48]$.

\section{Mechanism of action in cancer}

The anticancer effects of metformin are associated with both direct (insulin- independent) and indirect (insulindependent) actions of the drug (Figure 1). The indirect, insulin-dependent effects of metformin are mediated by the ability of AMPK to inhibit the transcription of key gluconeogenesis genes in the liver and stimulate glucose uptake in muscle, thus reducing fasting blood glucose and insulin $[1,20]$. The insulin-lowering effects of metformin may play a major role in its anticancer activity since insulin has mitogenic and prosurvival effects and tumor cells often express high levels of the insulin receptor, indicating a potential sensitivity to the growth 


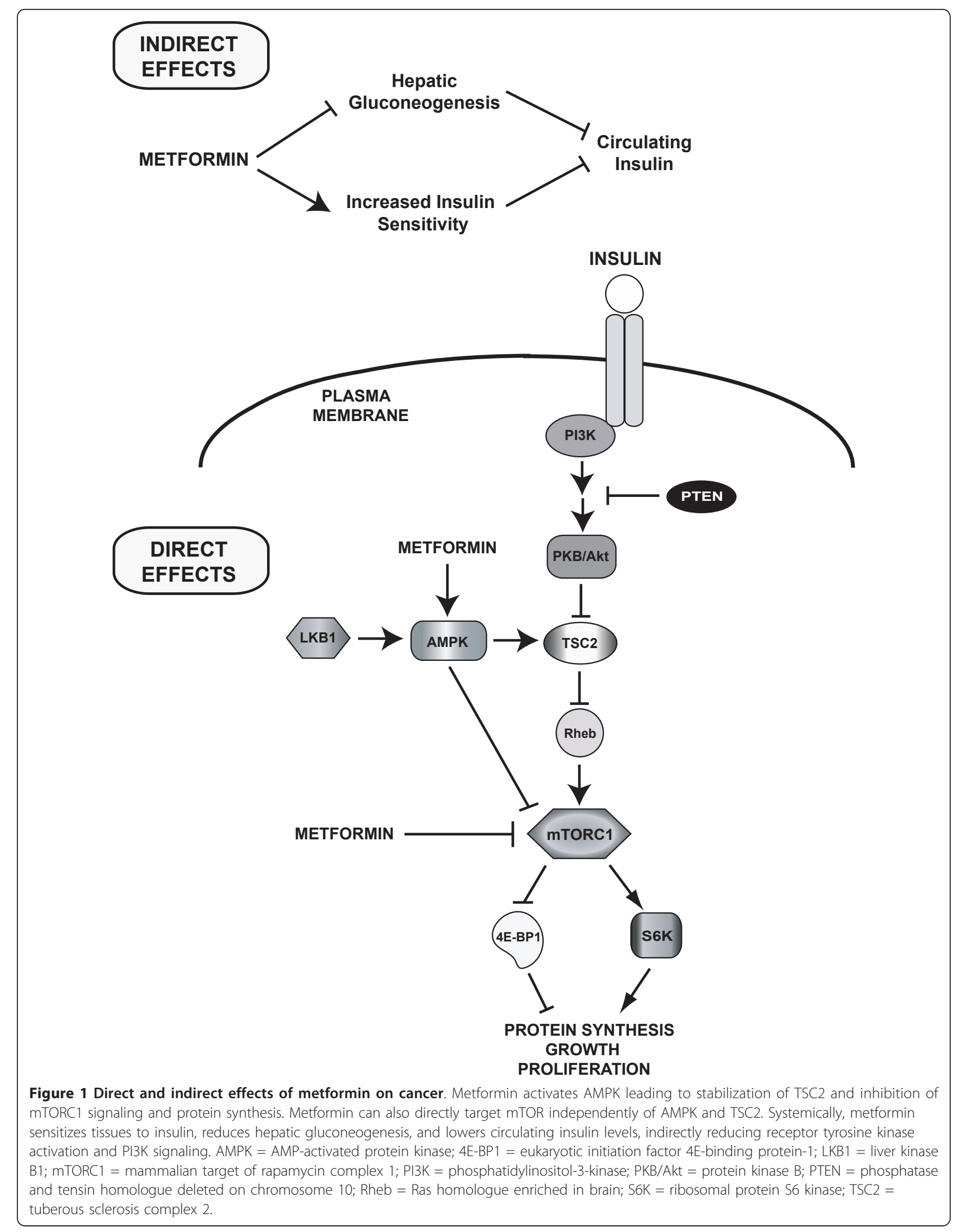


promoting effects of the hormone [49-51]. Further, obesity and high insulin levels are adverse prognostic factors for a number of cancers particularly those of the breast, prostate and colon [25,50,52-54]. Consequently, metformin may diminish the negative effects of insulin on tumor development and growth. Indeed, metformin suppressed the stimulatory effects of obesity and hyperinsulinemia on lung tumor growth in mice by improving insulin sensitivity, lowering circulating insulin, and activating AMPK signaling [13]. In addition, metformin reduced circulating insulin levels by $22 \%$ and improved insulin sensitivity by $25 \%$ in non-diabetic women with breast cancer, highlighting the insulin-lowering effects of metformin as a potential mechanism of action in the treatment of breast cancer [12].

The direct, insulin-independent effects of metformin originate from LKB1-mediated activation of AMPK and a reduction in $\mathrm{mTOR}$ signaling and protein synthesis in cancer cells [34] (Figure 1). AMPK impacts mTOR via phosphorylation and activation of the tumor suppressor tuberous sclerosis complex 2 (TSC2, tuberin), which negatively regulates mTOR activity [55]. mTOR is a key integrator of growth factor and nutrient signals and is a critical mediator of the phosphatidylinositol-3-kinase/ protein kinase $\mathrm{B} / \mathrm{Akt}$ (PI3K/PKB/Akt) signaling pathway, which is one of the most frequently deregulated molecular networks in human cancer [56,57]. Metforminmediated AMPK activation leads to an inhibition of mTOR signaling, a reduction in phosphorylation of its major downstream effectors, the eukaryotic initiation factor 4E-binding proteins (4E-BPs) and ribosomal protein S6 kinases (S6Ks), and an inhibition of global protein synthesis and proliferation in a number of different cancer cell lines $[34,35,40,58]$.

Some recent reports raise the possibility that metformin may mediate additional anticancer effects independently of AMPK, LKB1, and TSC2 [59,60]. Indeed, metformin reduced mTOR signaling independently of AMPK and TSC2 by inhibiting Rag GTPase-mediated activation of mTOR [59]. Paradoxically, at least in one cell model system, loss of function of LKB1 sensitized cells to the inhibitory effects of metformin under conditions of low glucose [61]. Moreover, metformin reduced hepatic gluconeogenesis by lowering hepatic energy levels in the absence of AMPK and LKB1 [60]. While these additional effects are intriguing, LKB1-dependent suppression of mTOR signaling remains the key candidate mechanism of antitumor action of metformin.

\section{Conclusions and future work with metformin in}

\section{cancer}

The clinical safety, well characterized pharmacodynamic profile, and low cost of metformin make it an ideal candidate for development as an anticancer agent. The recent convergence of epidemiologic, clinical and preclinical evidence supporting a potential anticancer effect of metformin has led to an explosion of interest in evaluating this agent in human cancer. However, a number of issues need further consideration in the development of metformin as a cancer therapy. In particular, the retrospective epidemiological studies that first identified the potential anticancer effects of metformin are difficult to confirm and contain only diabetic patient populations. While cell culture and mouse models have been integral to the characterization of the mechanism of action of metformin in the inhibition of cancer, they are artificial and rely on non-physiological doses of metformin in the presence of excess insulin and growth factors. New, more physiologically relevant in vitro models will be required to fully elucidate the mechanism of action of metformin (both the insulin-dependent and insulin-independent actions) and inform clinical studies. Furthermore, additional research is required to identify key patient and tumor factors that govern metformin sensitivity, which is critical for the design of clinical trials and the identification of patients best suited for metformin treatment. Current preclinical and clinical knowledge of metformin action suggest that patients exhibiting hyperinsulinemia and tumors expressing the insulin receptor, LKB1, and TSC2 would benefit most from metformin therapy, while patients with normal circulating insulin levels and tumors lacking expression of the insulin receptor, LKB1, and TSC2 would likely be unresponsive to the drug. Predicting how non-diabetic patients will respond to metformin and differentiating between its direct and indirect effects may be challenging. However, the initiation of new, focused clinical trials containing strong correlative science components will be crucial in understanding the effects of the drug on a range of cancer patients (including non-diabetic patients) and the identification of biomarkers that predict metformin benefit and response to therapy. Currently, a number of clinical trials examining the use of metformin as a cancer therapy are underway including studies in prostate, breast, endometrial and pancreatic cancer patients. In fact, the National Cancer Institute of Canada Clinical Trials Group (NCIC CTG) has initiated a large phase III clinical trial (NCIC CTG MA.32) examining the effect of metformin versus placebo in over 3,500 women with early stage breast cancer [62]. Coupled with the implementation of new preclinical models, these clinical trials will be integral to the development and effective use of metformin as a potential anticancer therapy.

\section{Acknowledgements}

Work in the laboratory of VS is supported by the Canadian Institutes of Health Research, Susan G. Komen Breast Cancer Foundation and the Canadian Breast Cancer Foundation, Ontario Branch. RD is supported by a MITACS Elevate postdoctoral fellowship. 


\section{Author details}

'Ontario Cancer Institute, University Health Network, Toronto, Ontario, Canada. ${ }^{2}$ Mount Sinai Hospital, Toronto, Ontario, Canada.

\section{Authors' contributions}

RD, PG and VS wrote the paper. All authors read and approved the final manuscript.

\section{Competing interests}

The authors declare that they have no competing interests.

Received: 19 January 2011 Accepted: 6 April 2011

Published: 6 April 2011

\section{References}

1. Witters LA: The blooming of the French lilac. J Clin Invest 2001, 108:1105-1107.

2. Hadden DR: Goat's rue - French lilac - Italian fitch - Spanish sainfoin: gallega officinalis and metformin: the Edinburgh connection. J $R$ Coll Physicians Edinb 2005, 35:258-260.

3. Bailey CJ, Day C: Metformin: its botanical background. Pract Diab Int 2004, 21:115-117.

4. Bailey CJ, Turner RC: Metformin. N Engl J Med 1996, 334:574-579.

5. Ben Sahra I, Le Marchand-Brustel Y, Tanti JF, Bost F: Metformin in cancer therapy: a new perspective for an old antidiabetic drug? Mol Cancer Ther 2010, 9:1092-1099.

6. Diamanti-Kandarakis E, Economou F, Palimeri S, Christakou C: Metformin in polycystic ovary syndrome. Ann N Y Acad Sci 1205:192-198.

7. Rotella CM, Monami M, Mannucci E: Metformin beyond diabetes: new life for an old drug. Curr Diabetes Rev 2006, 2:307-315.

8. Dilman VM, Berstein LM, Ostroumova MN, Fedorov SN, Poroshina TE, Tsyrlina EV, Buslaeva VP, Semiglazov VF, Seleznev IK, Bobrov YuF, Vasilyeva IA, Kondratjev VB, Nemirovsky VS, Nikiforov YF: Metabolic immunodepression and metabolic immunotherapy: an attempt of improvement in immunologic response in breast cancer patients by correction of metabolic disturbances. Oncology 1982, 39:13-19.

9. Dilman VM, Berstein LM, Yevtushenko TP, Tsyrlina YV, Ostroumova MN, Bobrov Yu F, Revskoy S, Kovalenko IG, Simonov NN: Preliminary evidence on metabolic rehabilitation of cancer patients. Arch Geschwulstforsch 1988, 58:175-183.

10. Berstein LM: Modern approach to metabolic rehabilitation of cancer patients: biguanides (phenformin and metformin) and beyond. Future Oncol 2010, 6:1313-1323.

11. Evans JM, Donnelly LA, Emslie-Smith AM, Alessi DR, Morris AD: Metformin and reduced risk of cancer in diabetic patients. BMJ 2005, 330:1304-1305.

12. Goodwin PJ, Pritchard KI, Ennis M, Clemons M, Graham M, Fantus IG: Insulin-lowering effects of metformin in women with early breast cancer. Clin Breast Cancer 2008, 8:501-505.

13. Algire C, Zakikhani M, Blouin MJ, Shuai JH, Pollak M: Metformin attenuates the stimulatory effect of a high-energy diet on in vivo LLC1 carcinoma growth. Endocr Relat Cancer 2008, 15:833-839.

14. Kahn BB, Alquier T, Carling D, Hardie DG: AMP-activated protein kinase: ancient energy gauge provides clues to modern understanding of metabolism. Cell Metab 2005, 1:15-25.

15. Zhou G, Myers R, Li Y, Chen Y, Shen X, Fenyk-Melody J, Wu M, Ventre J, Doebber T, Fujii N, Musi N, Hirshman MF, Goodyear $\sqcup$, Moller DE: Role of AMP-activated protein kinase in mechanism of metformin action. J Clin Invest 2001, 108:1167-1174.

16. El-Mir MY, Nogueira V, Fontaine E, Averet N, Rigoulet M, Leverve X: Dimethylbiguanide inhibits cell respiration via an indirect effect targeted on the respiratory chain complex I. J Biol Chem 2000, 275:223-228.

17. Shaw RJ, Kosmatka M, Bardeesy N, Hurley RL, Witters LA, DePinho RA, Cantley LC: The tumor suppressor LKB1 kinase directly activates AMPactivated kinase and regulates apoptosis in response to energy stress. Proc Natl Acad Sci USA 2004, 101:3329-3335.

18. Hardie DG: AMP-activated/SNF1 protein kinases: conserved guardians of cellular energy. Nat Rev Mol Cell Biol 2007, 8:774-785.

19. Towler MC, Hardie DG: AMP-activated protein kinase in metabolic control and insulin signaling. Circ Res 2007, 100:328-341.
20. Cusi K, Consoli A, DeFronzo RA: Metabolic effects of metformin on glucose and lactate metabolism in noninsulin-dependent diabetes mellitus. J Clin Endocrinol Metab 1996, 81:4059-4067.

21. Hundal RS, Krssak M, Dufour S, Laurent D, Lebon V, Chandramouli V, Inzucchi SE, Schumann WC, Petersen KF, Landau BR, Shulman Gl: Mechanism by which metformin reduces glucose production in type 2 diabetes. Diabetes 2000, 49:2063-2069.

22. Shaw RJ, Lamia KA, Vasquez D, Koo SH, Bardeesy N, Depinho RA, Montminy M, Cantley LC: The kinase LKB1 mediates glucose homeostasis in liver and therapeutic effects of metformin. Science 2005, 310:1642-1646.

23. Hardie DG: The AMP-activated protein kinase pathway-new players upstream and downstream. J Cell Sci 2004, 117:5479-5487.

24. Libby G, Donnelly LA, Donnan PT, Alessi DR, Morris AD, Evans JM: New users of metformin are at low risk of incident cancer: a cohort study among people with type 2 diabetes. Diabetes Care 2009, 32:1620-1625.

25. Decensi A, Puntoni M, Goodwin P, Cazzaniga M, Gennari A, Bonanni B, Gandini S: Metformin and cancer risk in diabetic patients: a systematic review and meta-analysis. Cancer Prev Res (Phila) 2010, 3:1451-1461.

26. Landman GW, Kleefstra N, van Hateren KJ, Groenier KH, Gans RO, Bilo HJ: Metformin associated with lower cancer mortality in type 2 diabetes: ZODIAC-16. Diabetes Care 2010, 33:322-326.

27. Monami M, Lamanna C, Balzi D, Marchionni N, Mannucci E: Sulphonylureas and cancer: a case-control study. Acta Diabetol 2009, 46:279-284.

28. Bowker SL, Majumdar SR, Veugelers P, Johnson JA: Increased cancerrelated mortality for patients with type 2 diabetes who use sulfonylureas or insulin. Diabetes Care 2006, 29:254-258.

29. Jiralerspong S, Palla SL, Giordano SH, Meric-Bernstam F, Liedtke C, Barnett CM, Hsu L, Hung MC, Hortobagyi GN, Gonzalez-Angulo AM: Metformin and pathologic complete responses to neoadjuvant chemotherapy in diabetic patients with breast cancer. J Clin Oncol 2009, 27:3297-3302.

30. Patel T, Hruby G, Badani K, Abate-Shen C, McKiernan JM: Clinical outcomes after radical prostatectomy in diabetic patients treated with metformin. Urology 76:1240-1244.

31. Hosono K, Endo H, Takahashi H, Sugiyama M, Sakai E, Uchiyama T, Suzuki K, lida H, Sakamoto Y, Yoneda K, Koide T, Tokoro C, Abe Y, Inamori M, Nakagama H, Nakajima A: Metformin suppresses colorectal aberrant crypt foci in a short-term clinical trial. Cancer Prev Res (Phila) 2010, 3:1077-1083.

32. Niraula S, Stambolic V, Dowling RJO, Ennis M, Chang MC, Done SJ, Hallak S, Hood N, Goodwin PJ: Clinical and biologic effects of metformin in early stage breast cancer. Cancer Res 2010, 70(24, Suppl):104s, Abs No. PD03-06.

33. Hadad SM, Dewar JA, Elseedawy E, Jordan LB, Purdie C, Bray SE, Thompson AM: Gene Signature of metformin actions on primary breast cancer within a window of opportunity randomized clinical trial. J Clin Oncol 2010, 28(Suppl):560.

34. Dowling RJ, Zakikhani M, Fantus IG, Pollak M, Sonenberg N: Metformin inhibits mammalian target of rapamycin-dependent translation initiation in breast cancer cells. Cancer Res 2007, 67:10804-10812.

35. Zakikhani M, Dowling R, Fantus IG, Sonenberg N, Pollak M: Metformin is an AMP kinase-dependent growth inhibitor for breast cancer cells. Cancer Res 2006, 66:10269-10273.

36. Ben Sahra I, Laurent K, Loubat A, Giorgetti-Peraldi S, Colosetti P, Auberger P, Tanti JF, Le Marchand-Brustel Y, Bost F: The antidiabetic drug metformin exerts an antitumoral effect in vitro and in vivo through a decrease of cyclin D1 level. Oncogene 2008, 27:3576-3586.

37. Buzzai M, Jones RG, Amaravadi RK, Lum JJ, DeBerardinis RJ, Zhao F, Viollet B, Thompson CB: Systemic treatment with the antidiabetic drug metformin selectively impairs p53-deficient tumor cell growth. Cancer Res 2007, 67:6745-6752.

38. Cantrell LA, Zhou C, Mendivil A, Malloy KM, Gehrig PA, Bae-Jump VL: Metformin is a potent inhibitor of endometrial cancer cell proliferationimplications for a novel treatment strategy. Gynecol Oncol 116:92-98.

39. Isakovic A, Harhaji L, Stevanovic D, Markovic Z, Sumarac-Dumanovic M, Starcevic V, Micic D, Trajkovic V: Dual antiglioma action of metformin: cell cycle arrest and mitochondria-dependent apoptosis. Cell Mol Life Sci 2007, 64:1290-1302.

40. Gotlieb WH, Saumet J, Beauchamp MC, Gu J, Lau S, Pollak MN, Bruchim I: In vitro metformin anti-neoplastic activity in epithelial ovarian cancer. Gynecol Oncol 2008, 110:246-250. 
41. Liu B, Fan Z, Edgerton SM, Deng XS, Alimova IN, Lind SE, Thor AD: Metformin induces unique biological and molecular responses in triple negative breast cancer cells. Cell Cycle 2009, 8:2031-2040.

42. Hirsch HA, Iliopoulos D, Tsichlis PN, Struhl K: Metformin selectively targets cancer stem cells, and acts together with chemotherapy to block tumor growth and prolong remission. Cancer Res 2009, 69:7507-7511.

43. Vazquez-Martin A, Oliveras-Ferraros C, Barco SD, Martin-Castillo B, Menendez JA: The anti-diabetic drug metformin suppresses self-renewal and proliferation of trastuzumab-resistant tumor-initiating breast cancer stem cells. Breast Cancer Res Treat 2011.

44. Vazquez-Martin A, Oliveras-Ferraros C, Cufi S, Del Barco S, Martin-Castillo B, Menendez JA: Metformin regulates breast cancer stem cell ontogeny by transcriptional regulation of the epithelial-mesenchymal transition (EMT) status. Cell Cycle 2010, 9:3807-3814.

45. Anisimov VN, Berstein LM, Egormin PA, Piskunova TS, Popovich IG, Zabezhinski MA, Kovalenko IG, Poroshina TE, Semenchenko AV, Provinciali M, Re F, Franceschi C: Effect of metformin on life span and on the development of spontaneous mammary tumors in HER-2/neu transgenic mice. Exp Gerontol 2005, 40:685-693.

46. Tomimoto A, Endo H, Sugiyama M, Fujisawa T, Hosono K, Takahashi H, Nakajima N, Nagashima Y, Wada K, Nakagama H, Nakajima A: Metformin suppresses intestinal polyp growth in ApcMin/+ mice. Cancer Sci 2008, 99:2136-2141.

47. Memmott RM, Mercado JR, Maier CR, Kawabata S, Fox SD, Dennis PA: Metformin prevents tobacco carcinogen-induced lung tumorigenesis. Cancer Prev Res (Phila) 2010, 3:1066-1076.

48. Hosono K, Endo H, Takahashi H, Sugiyama M, Uchiyama T, Suzuki K, Nozaki Y, Yoneda K, Fujita K, Yoneda M, Inamori M, Tomatsu A, Chihara T, Shimpo K, Nakagama H, Nakajima A: Metformin suppresses azoxymethane-induced colorectal aberrant crypt foci by activating AMPactivated protein kinase. Mol Carcinog 2010, 49:662-671.

49. Belfiore A, Frasca F: IGF and insulin receptor signaling in breast cancer. J Mammary Gland Biol Neoplasia 2008, 13:381-406.

50. Frasca F, Pandini G, Sciacca L, Pezzino V, Squatrito S, Belfiore A, Vigneri R: The role of insulin receptors and IGF-I receptors in cancer and other diseases. Arch Physiol Biochem 2008, 114:23-37.

51. Mulligan AM, O'Malley FP, Ennis M, Fantus IG, Goodwin PJ: Insulin receptor is an independent predictor of a favorable outcome in early stage breast cancer. Breast Cancer Res Treat 2007, 106:39-47.

52. Ish-Shalom D, Christoffersen CT, Vorwerk P, Sacerdoti-Sierra N, Shymko RM, Naor D, De Meyts P: Mitogenic properties of insulin and insulin analogues mediated by the insulin receptor. Diabetologia 1997, 40(Suppl 2):S25-31.

53. Basen-Engquist $\mathrm{K}$, Chang M: Obesity and cancer risk: recent review and evidence. Curr Oncol Rep 2011, 13:71-76.

54. Goodwin PJ, Ennis M, Pritchard KI, Trudeau ME, Koo J, Madarnas Y, Hartwick W, Hoffman B, Hood N: Fasting insulin and outcome in earlystage breast cancer: results of a prospective cohort study. J Clin Oncol 2002, 20:42-51.

55. Inoki K, Zhu T, Guan KL: TSC2 mediates cellular energy response to control cell growth and survival. Cell 2003, 115:577-590.

56. Lee JW, Soung YH, Kim SY, Lee HW, Park WS, Nam SW, Kim SH, Lee JY, Yoo NJ, Lee SH: PIK3CA gene is frequently mutated in breast carcinomas and hepatocellular carcinomas. Oncogene 2005, 24:1477-1480.

57. Markman B, Atzori F, Perez-Garcia J, Tabernero J, Baselga J: Status of PI3K inhibition and biomarker development in cancer therapeutics. Ann Oncol 2010, 21:683-691.

58. Alimova IN, Liu B, Fan Z, Edgerton SM, Dillon T, Lind SE, Thor AD: Metformin inhibits breast cancer cell growth, colony formation and induces cell cycle arrest in vitro. Cell Cycle 2009, 8:909-915.

59. Kalender A, Selvaraj A, Kim SY, Gulati P, Brûlé S, Viollet B, Kemp BE, Bardeesy N, Dennis P, Schlager JJ, Marette A, Kozma SC, Thomas G: Metformin, independent of AMPK, inhibits mTORC1 in a rag GTPasedependent manner. Cell Metab 2010, 11:390-401.

60. Foretz M, Hebrard S, Leclerc J, Zarrinpashneh E, Soty M, Mithieux G, Sakamoto K, Andreelli F, Viollet B: Metformin inhibits hepatic gluconeogenesis in mice independently of the LKB1/AMPK pathway via a decrease in hepatic energy state. J Clin Invest 2010, 120:2355-2369.

61. Algire C, Amrein L, Bazile M, David S, Zakikhani M, Pollak M: Diet and tumor LKB1 expression interact to determine sensitivity to antineoplastic effects of metformin in vivo. Oncogene 2011, 30:1174-1182.
62. Goodwin PJ, Stambolic V, Lemieux J, Chen BE, Parulekar WR, Gelmon KA, Hershman DL, Hobday TJ, Ligibel JA, Mayer IA, Pritchard KI, Whelan TJ, Rastogi P, Shepherd LE: Evaluation of metformin in early breast cancer: a modification of the traditional paradigm for clinical testing of anticancer agents. Breast Cancer Res Treat 2011, 126:215-220.

\section{Pre-publication history}

The pre-publication history for this paper can be accessed here: http://www.biomedcentral.com/1741-7015/9/33/prepub

doi:10.1186/1741-7015-9-33

Cite this article as: Dowling et al:: Understanding the benefit of metformin use in cancer treatment. BMC Medicine 2011 9:33.

\section{Submit your next manuscript to BioMed Central and take full advantage of:}

- Convenient online submission

- Thorough peer review

- No space constraints or color figure charges

- Immediate publication on acceptance

- Inclusion in PubMed, CAS, Scopus and Google Scholar

- Research which is freely available for redistribution

Submit your manuscript at www.biomedcentral.com/submit
Biomed Central 